\title{
EFFECT OF SUGAR SUBSTITUTION WITH DATES PUREE (Phoenix dactylifera L.) ON THE PHYSICAL AND ORGANOLEPTIC CHARACTERISTICS OF KEFIR ICE CREAM
}

\author{
Fahmi Arifan ${ }^{1)}$, Heni Rizqiati ${ }^{* 2)}$, Antonius Hintono ${ }^{2)}$, Nurwantoro ${ }^{2)}$, Siti Susanti ${ }^{2)}$, Luthfiyah Nur Sulistiyani ${ }^{3)}$ \\ 1) Departemen Teknologi Industri, Sekolah Vokasi, Universitas Diponegoro, Jl. Prof. Sudarto, Tembalang, Kec. \\ Tembalang, Kota Semarang, Jawa Tengah, Indonesia, 50275 \\ ${ }^{2)}$ Departemen Pertanian, Fakultas Peternakan dan Pertanian, Universitas Diponegoro, Jl. Prof. Soedarto, \\ Tembalang, Kec. Tembalang, Kota Semarang, Jawa Tengah, Indonesia, 50275 \\ 3) Mahasiswa Program Studi Teknologi Pangan, Universitas Diponegoro, Tembalang, Kec. Tembalang, Kota \\ Semarang, Jawa Tengah, Indonesia, 50275 \\ Email: henirizqi92@gmail.com
}

Submitted 26 October 2020; Accepted 21 January 2021

\begin{abstract}
The sour taste of kefir ice cream is less attractive with consumers, so it is necessary to add sweeteners. Dates can be used as a natural sweetener in making kefir ice cream. The aims of this research is to determine the effect of sugar substitution with dates puree on overrun, melting rates, viscosity, $\mathrm{pH}$ value and organoleptic properties of kefir ice cream. The method used in this research was an experimental with Completely Randomized Design (CRD) with 5 treatments and 4 replications. Overrun, melting rates, viscosity and $\mathrm{pH}$ values were analyzed by ANOVA test and followed by Duncan Multiple Range Test, meanwhile organoleptic characteristic were analyzed by Kruskall Wallis test and followed by Mann-Whitney test. The results showed that the substitution of sugar with dates puree as a sweetener had a significant effect $(\mathrm{p}<0.05)$ on overrun, melting rates, viscosity and $\mathrm{pH}$ value of kefir ice cream. Substitution of sugar with dates puree had a significant effect $(\mathrm{p}<0.05)$ on sweetness, sourness, brownish color and softness of kefir ice cream. The sugar substitution with dates puree $25 \%$ : $75 \%$ (T1) had the best overrun, melting rate as well as the organoleptic characteristic because it was able to reduce the sour taste of kefir ice cream.
\end{abstract}

Keywords: Dates puree; kefir ice cream; substitution. 


\section{INTRODUCTION}

Food processing technology are now currently growing, one of them is the processing of ice cream. In general, ice cream is made from a mixture of milk, animal or vegetable fat, sugar and with or without other food additives (Haryanti and Zueni, 2015). High nutritional value of ice cream is one of the benefits that can be obtained from consuming ice cream, but nowadays a lot of people choose to consume foods that have functional properties. One of the functional food that can be found nowaday is kefir. Kefir is a fermented product which is also consider as a functional food made from cow's milk fermented with kefir grains and contained about 40 types of beneficial bacteria (Rossi et al., 2016). Kefir has many health benefits, one of them is for digestion because it is known for the good bacteria in kefir that can inhibit the growth of pathogenic bacteria in the digestive system organ. The use of kefir in ice cream making is a new innovation and product diversification from kefir itself. However, ice cream has a fairly high level of acidity. The high acidity in kefir products is due to the high content of lactic acid produced from lactic acid bacteria in kefir grains and the presence of yeast which will convert milk lactose into $\mathrm{CO}_{2}$ and alcohol (Yusriah and Agustini, 2014). The sour taste of kefir products is one of the organoleptic properties of kefir which is still unpopular for the general public, so it is necessary to add sweetener.

A sweetener that is commonly used in food processing is sugar (sucrose). However, excessive sugar consumption is not good for health due to the high glycemic index (GI) and calorie content of sucrose

*Corresponding author:

Heni Rizqiati

Email: henirizqi92@gmail.com

Departemen Pertanian, Fakultas Peternakan dan

Pertanian, Universitas Diponegoro, Jl. Prof.

Soedarto, Tembalang, Kec. Tembalang, Kota

Semarang, Jawa Tengah, Indonesia, 50275
(Putri et al., 2015). An alternative that can be used to solve this problem is by substituting sugar with natural sweeteners from fruits, one of them is from dates puree. Dates are one of the fruits that have many benefits because of their high nutritional content. Dates have a high nutritional content and low in sucrose (Hasnaoui et al., 2011). Dates are classified as a very sweet fruits, however, dates have a relatively low glycemic index (GI) value (Maharani, 2018). Until now, the use of dates is still limited, dates are generally only consumed during Ramadan and are only consumed directly without going through further processing (Arisanti, 2017). The substitution treatment of dates puree will affect the physical and organoleptic characteristics of kefir ice cream.

The purpose of this study is to determine the effect of sugar substitution with dates puree on overrun, melting rates, viscosity, $\mathrm{pH}$ value, and organoleptic characteristic of kefir ice cream as well as food diversification by utilizing dates as natural sweeteners, resulting a healthy, nutritious and well-received food products.

\section{MATERIALS AND METHODS}

The research was carried out in September - October 2020 at the Laboratory of Engineering and Agricultural Products and Laboratory of Food Chemistry and Nutrition, Faculty of Animal Husbandry and Agriculture, Diponegoro University, Semarang. The materials in this research was kefir ice cream sugar substitution with dates puree. The materials used in this research were fresh cow milk, kefir grains obtained from Omah Kefir Ungaran, dates fruit Sukkari type, sugar, liquid whipping

How to cite:

Arifan, F., Rizqiati, H., Nurwanto, Susanti, S., Sulistiyani, L. N. (2021). Effect of sugar substitution with dates puree (Phoenix dactylifera L.) on the physical and organoleptic characteristics of kefir ice cream. Jurnal Ilmu dan Teknologi Hasil Ternak (JITEK), 16 (1), 21-31 
cream, egg yolk, Carboxymetyl cellulose (CMC), aquadest, and buffer solutions. The equipment used in this research were ice cream maker (Hakasima, Japan), hand mixer, pan, blender, filter, stirrer, thermometer, analytical scale, stove, pan, plastic wraps, plastic jars, refrigerator, freezer, beaker glass, cup and bob viscometer (Rion VT-06, Japan), stopwatch, $\mathrm{pH}$ meter (Ohaus-Starter2100, USA) and plastic cup. This research methods used by a completely randomized design (CRD) with 5 treatments and 4 replications. Substitution treatment of sugar and dates puree on kefir ice cream that was applied included T0 $($ control $)=100 \%$ sugar: $0 \%$ dates puree, $\mathrm{T} 1$ $=75 \%$ sugar: $25 \%$ dates puree, $\mathrm{T} 2=50 \%$ sugar: $50 \%$ dates puree, $\mathrm{T} 3=25 \%$ sugar: $75 \%$ dates puree, $\mathrm{T} 4=0 \%$ sugar: $100 \%$ dates puree. The procedures carried out in this research there are making kefir, making dates puree, making kefir ice cream with sugar substitution of dates puree and analyzing the samples by physical properties and organoleptic characteristics analyze.

\section{Kefir Preparation}

Fresh cow milk was filtered and pasteurized at $70^{\circ} \mathrm{C}$ for $15 \mathrm{~s}$. Then lowered the milk's temperature until it reached room temperature. The next step, 5\% of kefir grains were added from the total milk and stirred until blended, then the fermentation process is carried out at room temperature for $24 \mathrm{~h}$. After the fermentation process is completed, then filtered the kefir to separated the kefir from the kefir grains (Bayu et al., 2017).

\section{Dates Puree Preparation}

Dates were seperated from the seeds and then blended it until smooth with the addition of warm water, the ratio of water : dates was 1: 1. After that, the dates puree was filtered to separated the puree of the dates from the pulp (Ismail et al., 2018).

Table 1. Formulation of Kefir Ice Cream Sugar Subtition with Dates Puree

\begin{tabular}{lccccc}
\hline \multirow{2}{*}{ Ingredients } & \multicolumn{5}{c}{ Perlakuan } \\
\cline { 2 - 6 } & $\mathrm{T} 0$ & $\mathrm{~T} 1$ & $\mathrm{~T} 2$ & $\mathrm{~T} 3$ & $\mathrm{~T} 4$ \\
\hline Kefir $(\mathrm{g})$ & 255.38 & 255.38 & 255.38 & 255.38 & 255.38 \\
Whipped cream $(\mathrm{g})$ & 146.62 & 146.62 & 14662 & 146.62 & 146.62 \\
Sugar $(\mathrm{g})$ & 81.5 & 61.125 & 40.75 & 20.375 & - \\
Dates puree $(\mathrm{g})$ & - & 20.375 & 40.75 & 61.125 & 81.5 \\
Egg yolk $(\mathrm{g})$ & 15 & 15 & 15 & 15 & 15 \\
CMC $(\mathrm{g})$ & 1.5 & 1.5 & 1.5 & 1.5 & 1.5 \\
\hline Total $(\mathrm{g})$ & 500 & 500 & 500 & 500 & 500 \\
\hline
\end{tabular}

\section{Kefir Ice Cream Preaparation}

Kefir ice cream is made by pasteurized egg yolk first by HTST processed and then put it in a container for mixing process. Then, sugar and dates puree were added and mixed by using a hand mixer. Then, put in the liquid whipped cream and CMC then continued with the kefir and stired again evenly. After that, left the dough for $\pm 4 \mathrm{~h}$ on the refrigerator to pass the aging process. After the aging process completely done, put the dough into the ice cream maker for \pm $60 \mathrm{~min}$ then frozen it in the freezer at $-15^{\circ} \mathrm{C}$ for 24 h (Aulia et al., 2019).

\section{Variable Analysis: Overrun}

Overrun were measured based on the difference in ice cream mass and dough mass at the same ice cream volume. The overrun was calculated by weighing the ice cream dough before put into the ice cream maker as much $100 \mathrm{~mL}$ and the weight was recorded as $\mathrm{A}$.

After the dough came out of the ice cream maker, weigh the finished ice cream again as much $100 \mathrm{~mL}$ and record its weight as weight B (Sembiring et al., 2019). The overrun value can be calculated by: 


$$
\text { Overrun }=\frac{A-B}{A} \times 100 \%
$$

Information:

$\mathrm{A}=$ Weight of ice cream dough.

$\mathrm{B}=$ Weight of ice cream.

\section{Melting Rates}

Melting rates were analyzed by preparing $10 \mathrm{~g}$ of ice cream samples and placed them in the small cups and then freezed them in the freezer for $24 \mathrm{~h}$. After took out the ice cream samples from the freezer, then left them in an open place (room temperature), record the time for the ice cream samples to melt completely (Nofrida et al., 2018).

\section{Viscosity}

Viscosity were analyzed by using a rotary viscometer. Initially, a sample of $100 \mathrm{~mL}$ was inserted into the cup. Next, the cup is placed right in the middle of the viscometer rotor. The dough viscosity value will be shown on the monitor screen (Tamimi et al., 2019).

\section{pH Value}

$\mathrm{pH}$ value were measured by $\mathrm{pH}$ meter. Firstly, turned on the $\mathrm{pH}$ meter and calibrated it first. Samples were taken as much as $30 \mathrm{~mL}$ and then placed it into $50 \mathrm{~mL}$ beaker glass. The next step, $\mathrm{pH}$ meter cathode was inserted into the sample until a stable $\mathrm{pH}$ value appeared on the $\mathrm{pH}$ meter (Afriyani et al., 2020).

\section{Sensory Evaluation}

Organoleptic characteristic were tested using the scoring method including testing for sweetness, sourness, sour aroma, brownish color and softness. Organoleptic characteristic testing was carried out by using 25 semi-trained panelists. Each panelist would be presented with 5 different samples and they would be asked to give a score on the organoleptic characteristic of the ice cream with a rating scale of $1-4$ by descriptively (not - very) (Susilawati et al., 2014).

\section{Data Analysis}

All the data result from overrun, melting rates, viscosity and $\mathrm{pH}$ value were analyzed by using ANOVA test with a significant level of 5\% and if there was a significant effect then continued with Duncan Multiple Range Test. The data result from organoleptic characteristic test was analyzed using Kruskal Wallis test with a significant level of $5 \%$ and if there was a significant effect then continued with MannWhitney test.

\section{RESULTS AND DISCUSSION}

The results of kefir ice cream with dates puree as sugar substitution on overrun, melting rates, viscosity and $\mathrm{pH}$ value can be seen in Table 2. It is known that the sugar substitution with dates puree treatment on kefir ice cream had a significant effect $(\mathrm{p}<0.05)$ on overrun, melting rates, viscosity and $\mathrm{pH}$ value.

\section{Overrun}

Based on Table 2., The treatment of sugar substitution with dates puree on kefir ice cream had a significant effect $(\mathrm{p}<0.05)$ on the overrun of kefir ice cream. The highest overrun value was from T0 (without adding dates puree) which was $21.05 \%$, while the lowest overrun was from $\mathrm{T} 4$ (adding 100\% dates puree) which was $10.06 \%$. In general, overrun value for the household scale ranging from 30-50\% (Widiantoko and Yunianta, 2014). The results showed that the higher sugar substitution with dates puree on the kefir ice cream, gave the lower overrun value.

The decrease in the overrun value along with the higher concentration of dates puree substitution could be cause by an increase in the total solids of the ice cream. The higher total solids in the ice cream increase the viscosity or thickness of the ice cream, the high viscosity will affect the air trapping process in the ice cream which in turn will affect the overrun (Wijayanti et al., 2017). The thick ice cream dough will limit 
the mobility of the water molecules in the dough because the space between the particles is getting limited, the limited space between the particles causing the air to enter the dough during the agitation process only a little so the result for overrun is low
(Oksilia et al., 2012). Low overrun indicates the large number of solids contained so it takes a longer time to melt compared to ice cream which has a high overrun that contains more air bubbles (Rahmasari et al., 2019).

Table 2. Results of Testing the Physical Properties of Kefir Kurma Ice Cream

\begin{tabular}{lccccc}
\hline \multirow{2}{*}{ Parameter } & \multicolumn{5}{c}{ Treatment } \\
\cline { 2 - 6 } & $\mathrm{T} 0$ & $\mathrm{~T} 1$ & $\mathrm{~T} 2$ & $\mathrm{~T} 3$ & $\mathrm{~T} 4$ \\
\hline Overrun (\%) & $21.05 \pm 0.58^{\mathrm{e}}$ & $16.03 \pm 0.96^{\mathrm{d}}$ & $13.01 \pm 0.97^{\mathrm{c}}$ & $11.23 \pm 0.51^{\mathrm{b}}$ & $10.06 \pm 0.32^{\mathrm{a}}$ \\
Melting rates (min) & $25.18 \pm 1.71^{\mathrm{a}}$ & $30.27 \pm 2.71^{\mathrm{b}}$ & $32.69 \pm 1.86^{\mathrm{bc}}$ & $36.00 \pm 3.38^{\mathrm{cd}}$ & $39.10 \pm 2.11^{\mathrm{d}}$ \\
Viscocity (dPa.s) & $6.32 \pm 0.71^{\mathrm{a}}$ & $6.65 \pm 0.81^{\mathrm{ab}}$ & $7.35 \pm 0.24^{\mathrm{b}}$ & $8.40 \pm 0.08^{\mathrm{c}}$ & $8.80 \pm 0.27^{\mathrm{c}}$ \\
pH Value & $4.24 \pm 0.03^{\mathrm{a}}$ & $4.29 \pm 0.06^{\mathrm{ab}}$ & $4.32 \pm 0.07^{\mathrm{bc}}$ & $4.36 \pm 0.05^{\mathrm{bc}}$ & $4.40 \pm 0.05^{\mathrm{c}}$ \\
\hline
\end{tabular}

Remarks: * Different lowercase superscripts indicate are significantly effect $(\mathrm{p}<0.05)$

\section{Melting Rates}

Based on Table 2., it can be seen that kefir ice cream with the addition of dates puree as sugar substitution had a significant effect $(\mathrm{p}<0.05)$ on the melting rates of kefir ice cream. Dates puree substitution treatment significantly $(\mathrm{p}<0.05)$ increased the melting rates of kefir ice cream. It can be seen in Table 2., which showns that the melting rates of all samples treatment have from $25.18 \mathrm{~min}$ to $39.10 \mathrm{~min}$. The results of melting rates of kefir ice cream were significantly different because of the substitution treatment of dates puree due to the high total solids in dates puree. The increasing total solids contained in the dough will decrease the overrun value, while increasing the melting resistance of an ice cream (Nuryadi et al., 2020). Fiber is one of source of total solids in dates. The fiber content in dates is quite high, there is about 6.4 - 11.5\% (Sendra et al., 2016). The amount of fiber content in Sukkari dates is about $9.11 \%$ (Habib and Ibrahim, 2011).

The high total solids content in the ice cream dough will cause the water content in the dough to be less, so the ice crystals formed are also smaller. The formation of smaller ice crystals will make the ice cream more resistant to melting (Chen et al., 2019). Increasing the total amount of solids in the ice cream dough also has an effect in increasing the viscosity of the ice cream dough as well as the increasing resistance of the ice cream to melting. The viscosity of the dough has a significant effect on the resistance to melting and overrun of ice cream, the high viscosity will make the air trapped in the dough during the freezing process in the ICM will be difficult to enter, so the air cavity is small and causes the ice cream can not be melt easily at the room temperature (Ismail et al., 2020).

\section{Viscosity}

Based on Table 2., it can be seen that kefir ice cream with the addition of dates puree as sugar substitution had a significant effect $(p<0.05)$ on the ice cream viscosity. The highest viscosity observed in ice cream with higher date palm purees content (T4) and the lowest was found in sample with no added date palm purees (T0). The total solid contents in sokkary type of dates fruit range between 44.43 - 49.40\%. Meanwhile, $99 \%$ of the total material in sugar is total soluble solid content. The increase in viscosity can be associated with higher total solid contents that are able to trap and bind water (Sudajana et al., 2017). One of the components in total solid is sugar.

The main sugar content in sokkary dates is monosaccharides consisting of glucose $33.58 \%(\mathrm{~g} / 100 \mathrm{~g})$ and fructose $22.67 \%$ (g/100g) (Al-Asmari et al., 2017). While the main component of granulated sugar is sucrose which is a disaccharide group. Monosaccharides such as glucose 
and fructose have better hydrophilic and solubility characteristics than disaccharides so that resulting the solution easier to bind more water (Alizadeh et al., 2014). The fiber content in date fruit is also able to bind water which can cause a higher viscosity value (Syed et al., 2018). Viscosity is an important parameter in ice cream because it can be used as a measurement in the final quality of ice cream product. The viscosity can affect the smoothness, consistency and final texture of ice cream product. The higher viscosity of the ice cream mix, resulting high melting resistance but the overrun is reduced (Bahramparvar et al., 2010).

\section{pH Value}

Based on Table 2., it can be seen that kefir ice cream with the addition of dates puree as sugar substitution had a significant effect $(\mathrm{p}<0.05)$ on the $\mathrm{pH}$ value of kefir ice cream. Dates puree substitution treatment significantly $(\mathrm{p}<0.05)$ increased the $\mathrm{pH}$ value of kefir ice cream. The increase in $\mathrm{pH}$ value was due to the higher substitution of dates puree. The increase in the $\mathrm{pH}$ value of kefir ice cream products is thought to be due to the hydrolysis of cellulose starch from the fiber polysaccharide chain that occurs in solutions with acidic conditions.

In the acid state of cellulose, it will undergo hydrolysis, the $[\mathrm{H}+]$ ion can break the glycosidic bonds found in cellulose (Azizah and Marziah, 2018). Based on research that has been done by Mayang et al. (2019), along with the length of time for hydrolysis, the $\mathrm{pH}$ value of the product will be increase. It is suspected that there is a binding of free $[\mathrm{H}+]$ ions present in the solution with the molecules resulting from the breaking of the glycosidic bonds that occur during the hydrolysis of cellulose, so the free $[\mathrm{H}+]$ ions in the product decrease and increase the $\mathrm{pH}$ value. According to Hayyan et al. (2013), glucose has a neutral $\mathrm{pH}$ value.

The neutral $\mathrm{pH}$ value possessed by the glucose monomers from the hydrolysis of the cellulose is thought to increase the $\mathrm{pH}$ value of the resulting kefir ice cream. The
$\mathrm{pH}$ value in all treatments is in the range 4.24 - 4.40, this shown that the kefir ice cream still fullfils the standards of the Australia New Zealand Food Standards Code 2.5.3 (2015) regarding fermented milk products, that the $\mathrm{pH}$ value at fermented milk products not more than 4.5 .

\section{Organoleptic Characteristic Sweetness}

Based on Table 3., the results shown that the sweetness of kefir ice cream with the treatment of sugar substitution with dates puree had a significant effect $(p<0.05)$. The mean score of sweetness of kefir ice cream from T0 - T4 treatment was categorized as sweet - slightly sweet.

The sweetness of kefir ice cream is relatively reduced by the substitution of sugar with dates puree. This is can be happens because the total sugar content in dates is lower than sugar. The total sugar content of dates is $78.5 \%$ consisting of $3.2 \%$ sucrose (Soebahar et al., 2015). Meanwhile, sugar has high total sugar, it is about $99.9 \%$ sucrose (Listyaningrum et al., 2018). The reduced sweetness in kefir ice cream is also influenced by the lower use of sugar, meanwhile sugar can provide a better taste (Laga et al., 2019).

\section{Sourness}

Based on Table 3., the results shown that the sourness of kefir ice cream with the treatment of sugar substitution with dates puree had a significant effect $(\mathrm{p}<0.05)$. The mean score of sourness of kefir ice cream from T0 - T4 treatment was categorized as sour - slightly sour. The sour taste that appears in kefir ice cream comes from the breakdown of lactose into lactic acid during the fermentation process of kefir. Lactic acid bacteria in kefir will produce the $\beta$ galactosidase enzyme which can convert lactose sugar in milk into lactic acid which gives it a sour taste (Rumeen et al., 2015).

The sour taste of kefir ice cream tends to decrease along with the variation of dates puree substitutions. Dates are known as fruits that have a sweet taste, this is thought 
to reduce the sour taste of kefir ice cream (Seerangurayar et al., 2019). Dates fruit contain of reducing sugars such as a sucrose (Said et al., 2014).

\section{Sour Aroma}

Based on Table 3., the results shown that the sour aroma of kefir ice cream with the treatment of sugar substitution with dates puree did not have a significant effect. The mean score of sour aroma of kefir ice cream from T0 - T4 treatment was categorized as slightly acidic. The results that are not significantly different are thought to occur due to the effect of ice cream storage at low temperatures so that the detectability that can be felt is lower than other food products stored at room temperature (Simatupang et al., 2015). The aroma you feel is a sour aroma that arises from using kefir in the process of making ice cream.

Table 3. Results of Testing the Organoleptic Characteristic of Kefir Kurma Ice Cream

\begin{tabular}{lccccc}
\hline \multirow{2}{*}{ Parameter } & \multicolumn{5}{c}{ Treatment } \\
\cline { 2 - 6 } & $\mathrm{T} 0$ & $\mathrm{~T} 1$ & $\mathrm{~T} 2$ & $\mathrm{~T} 3$ & $\mathrm{~T} 4$ \\
\hline Sweetness & $2.64 \pm 0.91^{\mathrm{a}}$ & $2.64 \pm 0.81^{\mathrm{a}}$ & $2.28 \pm 0.84^{\mathrm{a}}$ & $1.72 \pm 0.68^{\mathrm{b}}$ & $1.58 \pm 0.65^{\mathrm{b}}$ \\
Sourness & $3.08 \pm 0.95^{\mathrm{a}}$ & $2.44 \pm 0.82^{\mathrm{b}}$ & $2.40 \pm 0.76^{\mathrm{b}}$ & $2.40 \pm 0.76^{\mathrm{b}}$ & $2.20 \pm 0.86^{\mathrm{b}}$ \\
Sour Aroma & $2.00 \pm 0.71$ & $2.12 \pm 0.72$ & $2.28 \pm 0.74$ & $2.32 \pm 0.80$ & $2.36 \pm 0.95$ \\
Brownish Color & $1.12 \pm 0.33^{\mathrm{a}}$ & $1.48 \pm 0.51^{\mathrm{b}}$ & $1.80 \pm 0.64^{\mathrm{b}}$ & $2.12 \pm 0.78^{\mathrm{bc}}$ & $2.24 \pm 0.83^{\mathrm{bc}}$ \\
Softness & $3.16 \pm 0.74^{\mathrm{a}}$ & $2.88 \pm 0.92^{\mathrm{ab}}$ & $2.60 \pm 0.91^{\mathrm{b}}$ & $2.56 \pm 0.96^{\mathrm{b}}$ & $2.28 \pm 0.84^{\mathrm{bc}}$ \\
\hline
\end{tabular}

Remarks: * Different lowercase superscripts indicate are significantly effect $(\mathrm{p}<0.05)$

The distinctive sour and yeast aroma in kefir is caused by the presence of dominant volatile ester compounds and lactic acid from the end result of the yeast fermentation process in kefir (Farag et al., 2020). The increase in orders for volatile compounds such as lactic acid, acetic acid and ethanol in the kefir fermentation process will increase the sharpness of the sour kefir aroma (Lestari et al., 2018). The aroma of a certain component has a specific function in food, including improving or sharpening the aroma of the product (Amir et al., 2017).

\section{Brownish Color}

Based on Table 3., the results shown that the brownish color of kefir ice cream with the treatment of sugar substitution with dates puree had a significant effect $(p<0.05)$. The mean score of brownish color of kefir ice cream from treatment T0 - T4 was categorized as not brownish - a little bit brownish. Data from further test results can be seen that the T0 treatment shows a significant difference with the $\mathrm{T} 1$ treatment. The brownish color of kefir ice cream is influenced by the substitution treatment of dates puree. The tannins in dates can have a brownish effect of the resulting kefir ice cream (Cesia and Judiono, 2018). The type dates that we were used are Sukkari, which have a golden brownish appearance (Astari and Dewi, 2019). The results obtained in the $\mathrm{T} 1$ to T4 treatment showed that there was no significant difference between treatments, this can be happens because Sukkari dates have a light brown color and the edges are goldish yellow (Fandi et al., 2020).

\section{Softness}

Based on Table 3., the results shown that the softness of kefir ice cream with the treatment of sugar substitution with dates puree had a significant effect $(p<0.05)$. The mean score of softness of kefir ice cream from T0 - T4 treatment was categorized as soft - not soft. The perceived softness can be influenced by several factors, one of which is total solids. Total solids can affect the texture of the ice cream produced as well as the softness of the ice cream (Tuhumury et $a l ., 2016)$. The addition of dates puree can reduces the softness of the ice cream because of dates fruit contain many fiber 
sources, so the texture of kefir ice cream becomes fibrous and feels flaky (Cesia and Judiono, 2018). The ideal ice cream texture is ice a smooth texture and has a small solid size (Baitirahman and Utami, 2019).

\section{CONCLUSION}

Based on the results presented, it is concluded that the sugar substitution with dates puree on kefir ice cream can reduce the overrun value and increase melting rates, viscosity and $\mathrm{pH}$ value of kefir ice cream. Sugar substitution with dates puree can reduce the sweetness, sourness and softness of kefir ice cream also increase the brownish color of kefir ice cream. Kefir ice cream substitution treatment of sugar with dates puree 25\%: $75 \%$ (T1) gave the best results seen from the overrun, melting rates as well as the organoleptic characteristic because it was able to reduce the sourness of kefir ice cream.

\section{ACKNOWLEDGMENT}

The authors wish to thank the Tanoto Student Research Award Foundation for financial support for this research.

\section{REFERENCES}

Afriyani, Y., Bakar, A. A., \& Dzarnisa, D. (2020). Pengaruh jenis pemanasan susu kambing terhadap sifat fisik dan kimia gelato kefir. Jurnal Ilmiah Mahasiswa Pertanian, 5 (1), 272-280. https://doi.org/10.17969/jimfp.v5i1.1 3767

Al-Asmari, F., Nirmal, N., Chaliha, M., Williams, D., Mereddy, R., Shelat, K., \& Sultanbawa, Y. (2017). Physicochemical characteristics and fungal profile of four Saudi fresh date (Phoenix dactylifera L.) cultivars. Food Chemistry, 221, 644-649. https://doi.org/10.1016/j.foodchem.20 16.11.125.

Alizadeh, M., Azizi-lalabadi, M., \& Kheirvari, S. (2014). Physicochemical, sensory, rheological properties and glycemic index of fresh date ice cream. Journal of Scientific Research and Reports, 621629. https://doi.org/10.9734/JSRR/2014/ 7178

Amir, F., Noviani, E., \& Widari, N. S. (2017). Pembuatan permen susu kambing etawa dengan menggunakan buah kurma sebagai pengganti gula. Jurnal Teknik UNIPA (WAKTU), 15 (1), 43-50.

Arisanti, D. (2017). Pengaruh sukrosa terhadap mutu kurma analog belimbing wuluh. Journal of Agritech Science (JASc), 1 (1), 26-31.

Astari, R. Y., \& Dewi, D. Y. (2019). Konsumsi kurma pada akhir kehamilan terhadap percepatan kala 1 persalinan. Wellness and Healthy Magazine, 1 (2), 177-185. https://doi.org/https://doi.org /10.30869/jasc.v1i01.6

Aulia, S., Rizqiati, H., \& N. Nurwantoro. (2019). Pengaruh substitusi kefir terhadap sifat fisik, total khamir dan hedonik es krim. Jurnal Teknologi Pangan, 3 (2), 192-198.

Azizah, Y., \& Marziah, A. (2018). Hidrolisis ampas tebu (Baggase) menggunakan $\mathrm{HCl}$ menjadi Cellulosa Powder. Jurnal Inovasi Ramah Lingkungan, 1 (2), 21-25.

Bahramparvar, M., Razavi, S. M., \& Khodaparast, M. H. (2010). Rheological characterization and sensory evaluation of a typical soft ice cream made with selected food hydrocolloids. Food Science and Technology International, 16 (1), 7988. https://doi.org/10.1177\%2F10820 13209353244

Baitirahman, A. N., \& Utami, N. P. (2019). Pengaruh penambahan varian ubi jalar terhadap sifat organoleptik es krim. Journal of Food and Culinary, 2 (1), 11-16. https://doi.org/10.12928/jfc.v2 i1.1527

Bayu, M. K., Rizqiati, H. dan Nurwantoro. 2017. Analisis total padatan terlarut, keasaman, kadar lemak, dan tingkat viskositas pada kefir optima dengan 
lama fermentasi yang berbeda. Jurnal Teknologi Pangan, 1 (2), 33-38.

Cesia A., \& Judiono, J. (2018). Formulasi es krim sari kurma. Jurnal Riset Kesehatan Poltekkes Depkes Bandung, 10 (1), 25. https://doi.org/ 10.34011/juriskesbdg.v10i1.113

Chen, W., Liang, G., Li, X., He, Z., Zeng, M., Gao, D., Qin, F., Goff, H. D., \& C. J. (2019). Effects of soy proteins and hydrolysates on fat globule coalescence and meltdown properties of ice cream. Food Hydrocolloids, 94, 279-286. https://doi.org/10.1016/j.fo odhyd.2019.02.045

Fandi, M., Nurhayati O. D., \& Isnanto, R. (2020). Aplikasi identifikasi jenis buah kurma dengan metode GLCM berbasis android. Jurnal Pengembangan Rekayasa Dan Teknologi, 16 (1), 34-44.

Farag, M. A., Jomaa, S. A., El-Wahed, A. A., \& El-Seedi., H. R. (2020). The many faces of kefir fermented dairy products: quality characteristics, flavour chemistry, nutritional value, health benefits, and safety. Nutrients, 12 (2), 346. https://doi.org/10.3390/ nu12020346

Habib, H. M., \& Ibrahim, W. H. (2011). Nutritional quality of 18 date fruit varieties. International Journal of Food Sciences and Nutrition, 62 (5), 544-551. https://doi.org/10.3109/096 37486.2011 .558073

Haryanti, N., \& Zueni, A. (2015). Identifikasi mutu fisik, kimia dan organoleptik es krim daging kulit manggis (Garcinia mangostana L.) dengan variasi susu krim. AGRITEPA: Jurnal Ilmu Dan Teknologi Pertanian, 2 (1), 143-156. https://doi.org/10.37 676/agritepa.v2i1.103

Hasnaoui, A., Elhoumaizi, A., Hakkou, A., Wathelet, B., \& Sindic, M. (2011). Physico-chemical characterization, classification and quality evaluation of date palm fruits of some Moroccan cultivars. Journal of Scientific Research and Reports, 3 (1), 139-149. https://doi.org/10.3329/jsr.v3i1.6062 Hayyan, A., Mjalli, F. S., AlNashef, I. M., Al-Wahaibi, Y. M., Al-Wahaibi, T., \& Hashim, M. A. (2013). Glucose-based deep eutectic solvents: Physical properties. Journal of Molecular Liquids, 178, 137-141.

Ismail, A. H., Hameed, A. M., Refaey, M.M., Sayqal, A., \& Aly, A. (2020). Rheological, physio-chemical and organoleptic characteristics of ice cream enriched with doum syrup and pomegranate peel. Journal of Chemistry, 13 (10), 7346-7356. https://doi.org/10.1016/j.arabjc.2020. 08.012

Ismail, E. A., Darni J., \& Setyorini, I. Y. (2018). Pengaruh substitusi sari kurma terhadap daya terima marmalade jeruk pamelo. Jurnal Nutrisi Darussalam, 2 (1), 1-10. http://dx.doi.org/10.21111/ dnj.v2i1.1956

Laga, A., Langkong, J., \& Muhpidah, M. (2019). Pengaruh penggunaan jenis gula terhadap mutu kurma tomat. Canrea Journal: Food Technology, Nutritions, and Culinary Journal, 2 (1), 62-68. https://doi.org/10.20956/ canrea.v2i1.212

Lestari, M. W., Bintoro V. P, \& Rizqiati, H. (2018). Pengaruh lama fermentasi terhadap tingkat keasaman, viskositas, kadar alkohol, dan mutu hedonik kefir air kelapa. Jurnal Teknologi Pangan, 2 (1), 42-50. https://doi.org/10.14710/ jtp.3.1.42\%E2\%80\%9350

Listyaningrum, C. E., Affandi, D. R., \& Zaman, M. Z. (2018). Pengaruh palm sugar sebagai pengganti sukrosa terhadap karakteristik snack bar tepung komposit (ubi ungu, jagung kuning dan kacang tunggak) sebagai snack rendah kalori. Jurnal Teknologi Hasil Pertanian, 11 (1), 53-62. https: //doi.org/10.20961/jthp.v11i1.29096

Maharani, S. (2018). Pengaruh pemberian mixed juice terhadap asupan energi ibu bersalin. Jurnal Akademika Baiturrahim Jambi, 7 (2), 114-122. http://dx.doi.org/10.36565/jab.v7i2.75 
Mayang, A. P., Sari, R. P., \& Fathoni, R. (2019). Pembuatan glukosa dari kulit pisang kepok (Musa paradisiaca L.) dengan proses hidrolisis. Jurnal Integrasi Proses, 8 (1), 39-44.

Motyl, W., Dziugan, P., Motyl, I., Jóźwiak, A., \& Nowak, S. (2019). Functional ice cream with a" clean label". Biotechnology and Food Science, 83 (2), 121-134. https://doi.org/10.346 58/bfs.2019.83.2.121-134

Nofrida, R., Sulastri, Y., Widyasari, R., Zaini, M. A., \& Nasrullah, A. (2018). Pengaruh penambahan stabilizer alami berbasis umbi lokal untuk peningkatan sifat fisik dan kimia es krim buah naga merah (Hylocereus Polyrhizus Sp.). Jurnal Ilmiah Teknologi Pertanian Agrotechno, 3 (1), 298-306. https://doi.org/10.248 43/JITPA.2018.v03.i01.p06

Nuryadi, A. M., Silaban D. P., Manurung, S., \& Apriani, S. W. (2020). Pemanfaatan buah matoa sebagai cita rasa es krim yang baru. Jurnal Penelitian Teknologi Industri, 11 (2), 9-16. http://dx.doi.org/10.33749/jpti. v11i2.5636

Oksilia, S., Syafutri, M. I., \& Lidiasari, E. (2012). Karakteristik es krim hasil modifikasi dengan formulasi bubur timun suri (Cucumis melo L.) dan sari kedelai. Jurnal Teknologi Dan Industri Pangan, 23 (1), 17-22.

Putri, R. M. S. P. S., Ninsix, R., \& Sari, A. (2015). Pengaruh jenis gula yang berbeda terhadap mutu permen jelly rumput laut (Eucheuma cottonii). Jurnal Teknologi Pertanian Andalas, 19 (1), 51-58. https://doi.org/10.250 77/jtpa.19.1.51-58.2015

Rahmasari E. A., Pramono, Y. B \& Hintono, A. (2019). Karakteristik daya leleh dan hedonik velva bengkuang berperisa bunga kecombrang dengan penambahan karagenan. Jurnal Teknologi Pangan, 3 (2), 292-297. https://doi.org/10.14710/jtp.3.2.292-297

Rossi, E., Hamzah, F., \& Febriyani, F. (2016). Perbandingan susu kambing dan susu kedelai dalam pembuatan kefir. Jurnal Peternakan Indonesia, 18 (1), 13-20. https://doi.org/10.25 077/jpi.18.1.13-20.2016

Rumeen, S. F., Yelnetty, A., Tamasoleng, M., \& Lontaan, N. (2015). Penggunaan level sukrosa terhadap sifat sensoris kefir susu sapi. Zootec, 38 (1), 123-130. https://doi.org/10.35 792/zot.38.1.2018.18565

Said, A., Kaoutrher, D., Ahmed, B., Mohammed, T., \& Brahim, T. (2014). Dates quality assessment of the main date palm cultivars grown in Algeria. Annual Research \& Review in Biology, 4 (3), 487-499. https:// doi.org/10.9734/ARRB/2014/5009

Seerangurayar, T., Al-Ismaili, A. M, Jeewantha, L. J., \& Al-Nabhani, A. (2019). Experimental investigation of shrinkage and microstructural properties of date fruits at three solar drying methods. Solar Energy, 180 (1), 445-455. https://doi.org/10.10 16/j.solener.2019.01.047

Sembiring, C.I., Legowo, A. M., \& Hintono, A. (2019). Pengaruh penambahan tepung umbi porang (Amorphophallus oncophyllus) sebagai penstabil terhadap sifat fisik, kimia dan organoleptik es krim nangka. Jurnal Teknologi Pangan, 3 (2), 241-246. https://doi.org/10.14710/jtp.3.2.241-246 Sendra, E., Pratamaningtyas., S., \& Panggayuh, A. (2016). Pengaruh konsumsi kurma (Phoenix dactylifera) terhadap kenaikan kadar hemoglobin pada ibu hamil trimester Ii di wilayah puskesmas Kediri. Jurnal Ilmu Kesehatan, 5 (1), 96-104.

Simatupang, T.P., Desmelati, \& Sari, N. I. (2015). Fortifikasi tepung ikan gabus (Channa striata) pada es krim rumput laut (Eucheuma cotonii) terhadap penerimaan konsumen. Jurnal Online Mahasiswa Fakultas Perikanan Dan Ilmu Kelautan Universitas Riau, 2 (2), $1-10$.

Soebahar, E., Daenuri, E., \& Firmansyah, A. (2015). Mengungkap rahasia buah 
kurma dan zaitun dari petunjuk hadis dan penjelasan sains. ULUL ALBAB Jurnal Studi Islam, 16 (2), 191-214. https://doi.org/10.18860/ua.v16i2.3181

Sudajana, F. L., Utomo, A. R., \& Kusumawati, N. (2017). Pengaruh penambahan berbagai konsentrasi NaCMC terhadap sifat fisikokimia dan organoleptik es krim sari biji nangka. Jurnal Teknologi Pangan Dan Gizi, 12 (1), 47-54. https://doi.org/10.33 508/jtpg.v12i1.1480

Susilawati, S., Nurainy, F., \& Nugraha, A. W. (2014). Pengaruh penambahan ubi jalar ungu terhadap sifat organoleptik es krim susu kambing peranakan etawa. Jurnal Teknologi Dan Industri Hasil Pertanian, 19 (3), 243-256. http://dx.doi.org/10.23960/jtihp.v19i3 $.243 \% 20-\% 20256$

Syed, Q. A., Anwar, S., Shukat, R., \& Zahoor, T. (2018). Effects of different ingredients on texture of ice cream. Journal of Nutritional Health and Food Engineering, 8 (6), 422-435. https://doi.org/10.15406/jnhfe.2018.0 8.00305 .

Tamimi, W., Nurwantoro, N., \& Bintoro, V. P. (2019). Karakteristik gelato susu kambing dengan penambahan ekstrak daun pegagan. Jurnal Teknologi Pangan, 3 (1), 51-62. https://doi.org/10.14710/jtp.3.1.51-62 Tuhumury, H. C., Nendissa, S. J., \& Rumra, M. (2016). Kajian sifat fisikokimia dan organoleptik es krim pisang tongka langit. AGRITEKNO: Jurnal Teknologi Pertanian, 5 (2), 46-52. https://doi.org/10.30598/jagritekno.20 16.5.2.46

Widiantoko, R.K. \& Y. Yunianta, Y. (2014). Pembuatan es krim tempe-jahe (kajian proporsi bahan dan penstabil terhadap sifat fisik, kimia dan organoleptik). Jurnal Pangan Dan Agroindustri, 2 (1), 54-66. http://dx.doi.org/10.217 76/jpa.v2i1.22

Wijayanti, I. A., Purwadi, P., \& Thohari, I. (2017). Pengaruh penambahan tepung sagu pada yoghurt terhadap viskositas, overrun, kecepatan meleleh dan total padatan es krim yoghurt. Jurnal Ilmu Dan Teknologi Hasil Ternak (JITEK), 10 (2), 28-35. https://doi.org/10.2 1776/ub.jitek.2015.010.02.3

Yusriah, N. H., \& Agustini, R. (2014). Pengaruh waktu fermentasi dan konsentrasi bibit kefir terhadap mutu kefir susu sapi. UNESA Jurnal of Chemistry, 3 (2), 53-57. 